\title{
REVITALISASI PSIKOLOGI AGAMA
}

\author{
Lukis Alam \\ Sekolah Tinggi Teknologi Nasional Yogyakarta \\ e-mail:lukisalam@gmail.com
}

\begin{abstract}
Abstrak
Jiwa merupakan salah satu entitas manusia, bilamana jiwa mendapatkan pengalaman yang berbeda menyikapi permasalahan maka akan terjadi goncangan yang dapat mempengaruhi pikiran. Sejatinya manusia diberikan intuisi untuk membedakan baik dan buruk. Dua hal ini dapat menjadi landasan dalam mempelajari unsurunsur psikologi dalam diri manusia yang dapat dikaitkan dengan pendekatan agama. Tulisan ini mencoba untuk mendudukkan konsep secara umum antara agama dan psikologi, tentunya dalam model deskriptif. Bahwa konsep psikologi agama lebih popular, hal itu sudah menjadi kelaziman karena antara psikologi dan agama saling terkait dan memberikan perspektif yang memadai. Oleh karena itu, psikologi agama dapat menjadi jembatan untuk menciptakan wawasan dalam memandang manusia terkait dengan fenomena-fenomena tertentu sehingga dapat memberikan kejelasan bagaimana hal tersebut menjadi logika yang bisa dinalar dengan akal sehat.
\end{abstract}

Kata Kunci: Psikologi, Agama, Manusia, Kehidupan, Jiwa

\section{A. Pendahuluan}

Kehidupan manusia tidak dapat dilepaskan dari berbagai macam aspek kebutuhan hidup, baik bersifat lahir maupun batin. Selain itu manusia juga membutuhkan pegangan hidup, yaitu agama, karena agama mengajarkan dan mengakui adanya Tuhan, terutama dalam Islam Allah Swt.. merupakan segalanya. Hal tersebut menjadi dasar bahwa manusia sejatinya membutuhkan Tuhan, maka manusia diberikan konsekuensi kepercayaan kepada sesuatu yang 
gaib. Menjalani kehidupan ini tidak lepas dari aspek supra-rasional.Hal itu membuat jiwa mengalami ketidakstabilan. Jiwa merupakan salah satu entitas manusia, bilamana jiwa mendapatkan pengalaman yang berbeda menyikapi permasalahan maka akan terjadi goncangan yang dapat mempengaruhi pikiran. Sejatinya manusia diberikan intuisi untuk membedakan baik dan buruk.Dua hal ini dapat menjadi landasan dalam mempelajari unsur-unsur psikologi dalam diri manusia yang dapat dikaitkan dengan pendekatan agama.

Tulisan ini mencoba untuk mendudukkan konsep secara umum antara agama dan psikologi, tentunya dalam model deskriptif. Bahwa konsep psikologi agama lebih popular, hal itu sudah menjadi kelaziman karena antara psikologi dan agama saling terkait dan memberikan perspektif yang memadai. Oleh karena itu, psikologi agama dapat menjadi jembatan untuk menciptakan wawasan dalam memandang manusia terkait dengan fenomena-fenomena tertentu sehingga dapat memberikan kejelasan bagaimana hal tersebut menjadi logika yang bisa dinalar dengan akal sehat.

\section{B. Konsep Dasar}

Agama menjadi identitas manusia dan merupakan elemen yang tidak terpisahkan dari kehidupan yang senantiasa dijalani. Agama dapat memfasilitasi segala aspek kehidupan manusia, tentunya Tuhan berbicara kepada manusia lewat agama. Oleh karena itu, manusia diberikan konsekuensi mempelajari agama supaya dia dapat berbicara dengan Tuhannya.Dalam aspek yang sama, agama merupakan salah satu konsekuensi yang harus dipegang dalam kehidupan di dunia.Ia merupakan pegangan supaya manusia dapat menjalani kehidupan ini sesuai dengan yang dikehendakinya. Agama menjadi koridor bagi kehidupan manusia.Agama menjadikan manusia menjadi makhluk yang taat, tunduk, patuh pada Tuhan yang bermuara terciptanya kehidupan yang dinamis dan bermakna. Oleh karena itu, agama menjadi aspek yang dibutuhkan manusia sehingga dari berbagai sudut pandang bahwa perspektif agama dan manusia tidak dapat dipisahkan.

Berdasarkan ayat di bawah ini, agama dipahami sebagai tata-aturan yang dapat memberikan perspektif kemajuan bagi manusia. Bukan berdasarkan sesuatu yang tidak ada padanannya, melainkan agama sebagai sarana yang dapat memberikan ketentraman, ketenangan yang pada akhirnya mendorong 
manusia senantiasa berbuat baik, memiliki akhlak terpuji dan etika sesuai dengan esensi-esensi sebagai manusia yang terhormat, memiliki derajat yang tinggi dibandingkan makhluk lain.

"Maka Kami berkata: "Hai Adam, sesungguhnya ini (iblis) adalah musuh bagimu dan bagi isterimu, maka sekali-kali janganlah sampai ia mengeluarkan kamu berdua dari surga, yang menyebabkan kamu menjadi celaka. Sesungguhnya kamu tidak akan kelaparan di dalamnya dan tidak akan telanjang. Dan sesungguhnya kamu tidak akan merasa dahaga dan tidak (pula) akan ditimpa panas matahari di dalamnya". (QS. Thaha: 117119).

Klaim agama-agama di dunia saat bahwa mereka membawa kebenaran yang mutlak. Jika dikatakan agama merupakan sandaran bagi keberadaan umat manusia hal itu tidak terbantahkan lagi, ${ }^{1}$ Bahkan aspek agama dapat masuk dalam pengertian yang multidimensional. Agama dapat memahami suatu fenomena, ilmu pengetahuan yang berkembang serta pandangan-pandangan interpersonal maupun intrapersonal, maka setiap pribadi akan mempercayai Tuhan sebagaiman Tuhan mengatur kehidupan mereka.

Masih dalam tataran yang sama, agama merupakan kekuatan sosial yang potensial. Sejarah membuktikan bahwa agama dapat memberikan semangat kepada setiap individu, menyatukan satu kelompok dengan kelompok lain. Karena agama merupakan bagian dari kekuatan sosial maka agama termasuk bagian kekuatan psikologis yang dapat mempengaruhi kehidupan manusia. ${ }^{2}$

Bagi sebagian orang, agama masih berkaitan dengan aspek transedental atau pengalaman mistik. Hal itu berkaitan dengan tingkah laku, perasaan, dan pengalaman masing-masing individu dalam kehidupan mereka. Terkadang dikaitkan dengan kepercayaan spiritual, hal itu pula yang menjadi perhatian dunia psikologi serta agama yang senantiasa diberikan pertanyaan mengapa harus percaya dengan Tuhan,kejadian-kejadian di luar nalar dan sebagainya. ${ }^{3}$

1 Van der Merwe, K., 2010, "A Psychological Perspective on the Source and Function of Religion", HTS Teologiese Studies/Theological Studies 66(1), Art. \#331, 8 pages. DOI: 10.4102/hts.v66i1.33.

2 Michael E. McCullough and Brian L. B. Willoughby, "Religion, Self-Regulation, and Self-Control: Associations, Explanations,and Implications," Psychological Bulletin, 2009, Vol. 135, No. 1, 69 $-93$.

3 Paul Bloom, Religin Morality,Evolution. Annu. Rev. Psychol. 2012.63:179-199. P. 183- 184. (Yale University, Sterling Chemistry Library). 
Dalam aspek lain, agama sering dikaitkan dengan konsep aktivitas sosial (social activity)/ interaksi dengan orang sehingga ketika berinteraksi dengan orang lain yang dikedepankan adalah moral. Maka, seringkali orang-orang mengaitkan bahwa ketika seseorang dapat bergaul dengan lingkungannya maka dia memiliki spiritual yang bagus karena agama mengajarkan hal demikian. ${ }^{4}$

Para ahli psikologi mempelajari bahwa religiusitas berkaitan erat dengan aspek psikologis (dunia psikologi).Mereka sepakat ternyata religiusitas (agama) memiliki dampak yang signifikan terhadap keadaan pribadi seseorang. Religiusitas menjadikan seseorang bahagia, selain itu dapat menciptakan perasaan yang relaks serta dapat menentramkan suasana. Hal ini dipadu dengan aspek psikologi yang mempelajari sikap dan pikiran seseorang, perpaduan sikap religiusitas dan aspek psikologi memunculkan suatu keilmuan yang berlandaskan pengaruh agama dan psikologi. ${ }^{5}$

Berlandaskan konsep dasar diatas, maka dalam mempelajari/ memahami agama memerlukan metode dalam mengeksplorasi pengalaman keberagamaan, salah satunya dengan pendekatan psikologis. Maka dari itu, penulis mendapatkan satu pola pendekatan yang membatasi topik ini, perumusan yang penulis dapatkan adalah bagaimana pendekatan psikologis dalam studi agama?

\section{Objek Kajian Psikologi Agama}

Penulis berpendapat bahwa kehadiran agama tidak hanya sebagai formalitas kehidupan, tetapi seharusnya dinamisator agar terlibat aktif dalam memecahkan pelbagai persoalan yang senantiasa semakin rumit dihadapi oleh umat manusia.Maka, domain utama dari keberadaan agama semata tidak boleh menjadi lambing falsifikasi terhadap suatu kejadian atau menjadi ajaran dogmatis. Bila sudah menjadi hal yang senantiasa dogmatis, maka agama dapat menjadi konsumsi untuk kepentingan tertentu. Menurut pendapat penulis selama ini bila memahami agama masih menggunakan aspek teologis

\footnotetext{
4 Ibid.

5 Shobina Joshi, Shilpa Kumari \& Madhu Jain, "Religious Belief and Its Relation to Psychological Well-being,"Journal of the Indian Academy of Applied Psychology, July 2008, Vol. 34, No.2,p. 345354.
} 
normatif yang terkadang bila dihadapkan pada kejadian atau permasalahan yang kompleks tidak dapat menjadi problem solving yang tuntas.

Sebagaimana yang sudah dibahas dalam konsep dasar diatas, dalam mempelajari agama tentunya memerlukan berbagai macam metode, salah satunya adalah aspek psikologi. Penulis tidak akan memaparkan definisi psikologi, karena sudah menjadi perhatian semua kalangan ketika berbicara aspek psikologi sedikit banyak sudah diketahui secara terminologisnya.

Menurut Zakiah Derajat, aspek psikologi dapat mempengaruhi seseorang yang dapat direpresentasikan dalam bentuk dhohir karena sikap religiusitas atau keyakinan spiritual yang dianutnya. Hal itu terimplementasikan kepada sikap-sikap percaya kepada keberadaan Tuhan yang menjadi keyakinannya, sebagaimana dicontohkan sikap seseorang terhadap keyakinan yang kuat bahwa Tuhan berperan dalam kehidupannya sehari-hari, terutama sikap iman dan takwa kepada Tuhan Yang Maha Esa, serta perilaku terpuji yang diwujudkan dari sifat-sifat yang dimiliki manusia yang secara kodrati manusia harus berbuat baik kepada sesamanya. Bila sudah demikian itu merupakan aspek-aspek kejiwaan (psikologis) yang bertautan dengan nilai-nilai religiusitas (agama). ${ }^{6}$

Masih menurut Zakiah Derajat, objek kajian psikologi agama diantaranya ${ }^{7}$ :

1. Bermacam-macam emosi yang menjalar diluar kesadaran yang ikut menyertai kehidupan beragama orang biasa (umum), seperti rasa lega dan tentram setelah selesai sholat, rasa lepas dari ketegangan batin sesudah berdoa atau membaca ayat-ayat suci, perasaan tenang, pasrah dan menyerah setelah berdzikir dan ingat kepada Allah ketika mengalami kesedihan dan kekecewaan yang dialaminya.

2. Bagaimana perasaan dan pengalaman seseorang secara individual kepada Tuhannya, misalnya merasa tentram dan kelegaan batin.

3. Mempelajari, meneliti, dan menganalisis pengaruh kepercayaan akan adanya hidup setelah mati (akhirat) pada tiap-tiap orang.

6 Zakiah Daradjat, Ilmu Jiwa Agama, (Jakarta: Bulan Bintang, 1987),hlm. 76.

7 Hamdani Bakran, Konseling dan Psikoterapi Islam, (Yogyakarta: Al Manar, 2008), hlm. 27-28. 
4. Meneliti dan mempelajari kesadaran dan perasaan orang terhadap kepercayaan yang berhubungan dengan surga dan neraka serta dosa dan pahala yang turut memberi pengaruh terhadap sikap dan tingkah lakunya dalam kehidupan.

5. Meneliti dan mempelajari bagaimana pengaruh penghayatan seseorang terhadap ayat-ayat suci dan kelegaan batinnya.

Agama dapat menjadi patokan bagi setiap orang manakala dia telah menemukan Tuhan dalam kehidupan sehari-hari, direpresentasikan dengan sikap seseorang yang beriman dan bertakwa kepada Allah Swt., berperilaku sebagai orang saleh dan seterusnya. Dari sinilah pendekatan agama dapat digunakan untuk mengetahui atau mempelajari Islam. Nama lain psikologi adalah ilmu jiwa yang mencoba mengetahui tingkat keberagamaan yang dihayati, dipahami, dan diamalkan. Pada tingkatan tertentu psikologi juga dapat dimasukkan ke dalam aspek agama sesuai tingkat usia seseorang. Maka, aspek psikologi inilah akan lebih dekat dijadikan sebagai tool (metode) dalam mempelajari aspek agama. ${ }^{8}$

Penulis mencoba memahami realitas agama dikaitkan dengan psikologi memang memunculkan dimanika tersendiri. Maka, bila agama mendapatkan perhatian dengan berbagai metode terutama psikologi, kemudian agama diinterpretasikan melalui pendekatan psikologis akan memunculkan paradigma psikologi agama. Secara implisit objeknya adalah manusia, yang akan membicarakan tingkah laku manusia yang memiliki keyakinan atau agama, symptom (gejala) yang muncul dari aktivitas keberagamaan yang dilakukan. Perlu diketahui bahwa metode ini tidak sampai pada judging (menilai) benar atau tidaknya suatu agama, apakah diwahyukan atau tidak, serta masalah-masalah yang tidak empiris lainnya sehingga lebih kepada logika mempelajari agama itu sendiri. ${ }^{9}$

Sependapat dengan pendapat diatas, menurut Raharjo bahwa psikologi tidak untuk membuktikan benar tidaknya suatu agama tertentu. Namun, lebih kepada keadaan manusia dari aspek kejiwaan, yang terlihat dari perilaku dan

8 Nur Khasanah, "Kombinasi Pendekatan Studi Islam: Ikhtiar Menjawab Tantangan Studi Islam Ke Depan," DalamRELIGIA Vol. 15 No. 1, April 2012. Hlm. 107-124.

9 Adeg Muchtar Ghazali, Ilmu Perbandingan Agama, (Bandung: CV Pustaka Setia, 2000), hlm. 4647. 
sifat kepribadian yang ia miliki. Aspek psikologi mencoba untuk memecahkan permasalahan yang ada pada diri manusia, bagaimana ia percaya dengan Tuhan bahkan ada yang tidak percaya dengan Tuhan. Kepercayaan itu timbul karena sikap manusia yang memiliki naluri akan kepercayaan kepada yang gaib setelah ia tertimpa musibah atau cobaan hidup. Pada sisi lain ada juga manusia yang hanya mengandalkan logika saja, tidak mungkin terciptanya segala sesuatu tanpa ada Creator (Sang Pencipta), maka logikanya menuntun kepada logika Tuhan sebagai Creator tersebut. ${ }^{10}$

Objek formal telaah psikologi adalah manusia dan objek materialnya adalah tingkah laku manusia. ${ }^{11}$ Keberadaan manusia telah banyak dibahas didalam Al-Qurandi antaranya adalah tentang sifat-sifat dan potensinya. Manusia merupakan makhluk ciptaan Tuhan dalam bentuk yang paling sempurna dibanding makhluk lainnya. ${ }^{12}$ Kesempurnaan manusia ini dibuktikan dengan pemberian akal yang dapat digunakan untuk membedakan yang baik dan yang buruk, benar dan salah. Manusia dianjurkan mencari kebenaran untuk menjalani hidup di dunia dan di akhirat kelak karena secara alamiah manusia mempunyai potensi diri.

Proses aktualisasi potensi itu merupakan pencapaian tujuan akhir pendidikan Islam. Islam dapat dilihat mempunyai dua komponen, yaitu ibadah (aktivitas penyembahan) dan mu'amalah (interaksi dengan sesama manusia). ${ }^{13}$ Keduanya terjalin secara erat dan saling berkaitan dalam banyak hal. Interaksi dengan sesama dan keterkaitan atas keduanya yang dipengaruhi oleh perasaan, pikiran, dan kemauan yang dimiliki oleh manusia akan menghasilkan pengakuan, yaitu pengakuan atas keberadaan dan tanggung jawabnya sebagai abdullah dan khalifah.

Sementara untuk mengaktualisasikan tugas ganda sebagai عبد الس dan خليفة maka Allah telah melengkapi manusia dengan sejumlah potensi dalam

10 Raharjo, Pengantar Ilmu Jiwa Agama, (Semarang: Pustaka Rizki Putra, 2012), hlm. 17.

11 Baharuddin, Aktualisasi Psikologi Islam,Cet.I, (Yogyakarta: Pustaka Pelajar, 2005), hlm.287.

12 Bentuk yang paling sempurna tersebut dilengkapi lagi dengan Aql. Al-Aqldapat bermakna kecerdasan karena itulah manusia dapat mengikat dan menahan hawa nafsunya. Dengan $A q l$ tersebut, manusia mampu membedakan mana yang hak dan mana yang batil. Lihat, Baharuddin, Paradigma Psikologi Islam, (Yogyakarta: Pustaka Pelajar, 2004), hlm. 115.

13 Mahmoud M. Ayoub, Islam: Antara Keyakinan \& Praktik Ritual, Refleksi Cendikiawan Muslim Untuk Kesadaran dan Kesatuan Umat, terj. Nur Hidayat (Yogyakarta: AK. Group, 2004), hlm. 125. 
dirinya. Potensi yang dapat menjalankan tugas dan tanggung jawab adalah al-Nafs, ${ }^{14}$ al-'Aql, ${ }^{15}$ dan al-Qalb. ${ }^{16}$ Dimensi nafsu memiliki dua daya utama, yaitu daya ghadab (marah) dan daya syahwat (senang). Daya ghadab adalah daya untuk menghindari sesuatu yang membahayakan atau hal yang tidak menyenangkan. Sementara itu, daya syahwat adalah daya untuk merebut dan mendorong kepada hal-hal yang memberikan kenikmatannya.

Sementara dimensi Aql memiliki daya mengetahui dan memahami. Daya mengetahui itu muncul sebagai akibat adaya daya pikir seperti memikirkan, memperhatikan, menginterpretasikan. Lain halnya dimensi Qalb memiliki dua daya, yaitu daya memahami dan daya merasakan. Daya memahami pada Qalb (disamping menggunakan daya memahami dan merasakan) memiliki daya persepsi Ruhaniah yang sifatnya menerima, yaitu memahami yang haq dan ilham /ilmu dari Tuhan. Dengan demikian, jiwa manusia mampu menangkap pengetahuan dengan dua cara, yaitu dengan menggunakan Aql dan Qalb. ${ }^{17}$

Manusia bebas menentukan tingkah lakunya berdasarkan pikiran, perasaan, dan kemauannya.Namun, pada saat yang bersamaan, manusia juga bertanggung jawab terhadap lingkungan alam, manusia, dan Tuhannya. Tanggung jawabnya terhadap alam adalah untuk melestarikannya, tanggung jawabnya terhadap sesama manusia adalah mensejahterakannya, dan tanggung jawab terhadap Tuhan adalah untuk mencari Ridla-Nya.

Islam sebagai petunjuk tentang ketundukan total kepada Allah dimaksudkan tidak hanya bagi orang-orang tertentu, tetapi bagi seluruh umat manusia. Universalisme Islam ini berarti bahwa semua manusia, baik sesama individu, sesama kelompok, maupun sesama bangsa adalah sama dihadapan Allah. Seseorang atau kelompok tidak dinilai berdasarkan keturunan atau kesempurnaan

14 Kata nafs menunjukkan manusia sebagai makhluk hidup yang asalnya satu, berkembang biak, bekerja dan merasa. Kata nafs juga kadang menunjukkan watak dan inti manusia. Lihat, Hasan Langgulung, Asas-asas Pendidikan Islam (Jakarta: Pustaka Al-Husna Baru, 2003), hlm. 265.

15 Kata al-'Aql dalam Al-Quran dengan berbagai bentuknya sebagai kata kerja yang semuanya menunjukkan arti pemikiran pada manusia. Dimensi inilah yang membedakan manusia dengan makhluk lain. Ibid., hlm. 267.

16 Arti al-Qalb kebanyakan berkisar pada arti perasaan dan intelektual manusia. Oleh karena itu, ia sebagai dasar bagi fitrah yang sehat. Tetapi al-Qalb tidak selalu merupakan wadah petunjuk dan iman tetapi kadang juga menunjukkan kepada dosa dan maksiat seperti yang terdapat pada QS. Al-Hijr, 15 : 12, QS. Al-Baqarah, 2: 283. Ibid., hlm. 266.

17 Baharuddin, Aktualisasi Psikologi Islam, Cet. I, (Yogyakarta: Pustaka Pelajar, 2005), hlm. 233-235. 
fisik seseorang, tetapi berdasarkan keimanan, kehidupan yang lebih baik, dan perhatiannya kepada kesejahteraan orang lain. ${ }^{18}$

\section{Relasi Pendekatan Psikologi dan Studi Islam}

Berangkat dari berbagai mahzab pemikiran masing-masing dan dengan menggunakan berbagai metode pendekatan maka para ahli di bidang psikologi juga menerapkannya untuk studi terhadap agama. Penelitian di bidang psikologi agama ini diawali dengan William James dengan karya besarnya The Varieties of Religious Experience yang kemudian diikuti dengan karya-karya para ahli lain dengan berbagai pendekatan dan kesimpulannya. William James membedakan dua bentuk agama, yaitu agama institusional (institutional religion)dan agama personal (personal religion). ${ }^{19} \mathrm{Hal}$ yang pertama mengacu pada kelompok-kelompok keagamaan yang berperan penting dalam kebudayaan masyarakat, yang kedua adalah mengacu pada pengalaman mistis seseorang yang bersifat individual. ${ }^{20}$

Agama personal dibedakan olehnya menjadi dua kategori, yaitu agama pikiran yang sehat(healthy minded religiousness) dan agama jiwa yang sakit (sick souled religiousness). Kategori pertama berpusat pada hal-hal yang positif dan kebaikan, sedangkan hal sebaliknya pada yang kedua lebihmemperhatikan masalah kejahatan dan penderitaan.

Filsafat pragmatisme yang dikembangkannya diterapkan pada agama sehingga mengatakanapabila seseorang percaya pada suatu agama dan menjalankan hal-hal terkait dengan kepercayaannya(ritual ibadah misalnya) dan hal itu membawa manfaat maka agama itu adalah cocok dan tepat baginya, sedangkan apabila hal itu tidak membawa suatu manfaat maka tidak ada alasan rasional untuk tetap mempertahankan agama itu baginya.

Sigmund Freud dengan teori psikoanalisanya, menerangkan sebagian besar perilaku manusia diatur oleh insting atau naluri.Dalam hal ini naluri atau insting bagian dari jiwa manusia. ${ }^{21}$ Dalam teorinya Freud menjelaskan,

18 Ibid.hlm.92.

19 "Psychology of Religion," Dalam Wikipedia, http:/len.wikipedia.org/wiki/ Psychology_of_religion

20 Ibid.

21 Hasan Langgulung, Teori-Teori Kesehatan Mental,Cet. II (Jakarta: Pustaka al-Husna, 1992), hlm. 92-93. 
kebutuhan fisik yang memotivasi orang untuk memuaskannya sehingga proses fisik mencapai keseimbangan. Insting (jiwa) didefinisikan sebagai perwujudan psikologis dari suatu sumber rangsangan somatik dalam yang dibawa sejak lahir. Perwujudan psikologisnya disebut hasrat, sedangkan rangsangan jasmaniahnya dari mana hasrat itu muncul disebut kebutuhan. Dengan kata lain, insting menjalankan kontrol selektif tingkah laku dengan meningkatkan kepekaan orang terhadap jenis-jenis stimulus tertentu, dan insting menurut Freud; suatu ukuran tuntutan pada jiwa untuk bekerja. ${ }^{22}$

Oleh karena itu, konsep teori kejiwaannya dirumuskan dengan teori kepribadian. Dengan merumuskan jiwa dengan tiga sistem yang membentuk perilaku kepribadiannya, yaitu id yang merupakan aspek biologis (dorongandorongan yang minta dipuaskan), ego sebagai aspek psikologis (nilai luhur yang diterima individu dari lingkungannya), dan super ego sebagai aspek sosiologis (norma masyarakat). ${ }^{23}$

Pada dasarnya Freud memandang agama sebagai sebuah ilusi yang harus dibuang untuk menujukepada kematangan kejiwaan, sebuah neurosis obsessional yang bersifat universal. Demikian pula sebaliknya, dia memandang neurosis obsessional sebagai sebuah sistem agama individual.Dengan mengacu pada August Comte yang membagi perkembangan manusia menjadi tiga tahapintelektual, yang pertama adalah tahap teologis yang mana posisi Tuhan dominan disana. Kedua, tahapmetafisika yang mana semua coba dijelaskan dengan filsafat, Freud berpendapat bahwa dengan psikoanalisis yang dikembangkannya maka manusia dapat memasuki tahapan perkembangan ketigayang paling maju, yaitu tahap ilmiah yang mana semua hal dipahami dengan prinsip ilmiah. ${ }^{24}$

Tokoh lainnya adalah Thomas Kuhn dalam bukunya The Structure of Scientific Revolution menyebut gelombang revolusi ilmu pengetahuan selalu ditandai oleh pergesaran dan pergantian dominasi ilmu pengetahuan

22 Iin Tri Rahayu, Psikoterapi Prespektif Islam dan Psikologi Kontemporer(Yogyakarta: Sukses Offset, 2009), hlm. 42-43.

23 Siti Sundari, Kesehatan Mental Dalam Kehidupan, (Jakarta: PT Rineka Cipta, 2005), hlm. 19.

24 Dalam Future of Illusion, Freud sangat yakin bahwa psikologinya sudah cukup untuk kepercayaan agama terutama yang berkaitan dengan Tuhan dan keabadian. "Freud, Sigmund"dalam Encyclopaedia Americana International Edition. 2004. Conecticut. Scholastic Library Publishing, Inc hlm 87 
yang berlaku. Cara pandang Thomas Kuhn dapat digunakan untuk melihat perkembangan pemikiran Psikologi yang juga mengalami pergeseran dan pergantian paradigma. Keadaan ini mengisyaratkan bahwa terbuka peluang untuk menghadirkan paradigma baru dalam kancah pemikiran Psikologi terutama bila terjadi krisis. ${ }^{25}$

Seperti dalam disiplin ilmu lainnya, pergeseran dan pergantian paradigma dalam pemikiran psikologi juga terjadi. Mazhab-mazhab Psikologi yang berdimensi horisontal dengan trial and error lahir. Dimulai dengan mazhab Psikoanalisis yang menganggap manusia sebagai Homo volens, makhluk yang perilakunya dikendalikan alam bawah sadar. Mazhab ini lahir ketika sains dipuja sebagai juru selamat umat manusia. Aliran ini dikoreksi oleh mazhab Behaviorisme yang menempatkan manusia sebagaiHomo mechanicus, makhluk yang dikendalikan faktor luar. Mazhab ini lahir ketika metode ilmiah dipercaya sebagai satu-satunya cara mengetahui yang dapat diandalkan. Selanjutnya, muncul mazhab Humanisme yang menganggap manusia memiliki kebebasan dalam menemukan makna hidup (Homo ludens). Aliran ini lahir ketika kelas menengah Amerika menikmati kemakmuran material dan menderita kekosongan spiritual. Ketika terjadi perubahan politik, budaya dan agama, tuntutan HAM, Gender dan hak kaum homoseks, lahirlah mazhab Transpersonal yang menganggap manusia memiliki potensi luhur/spiritual, ia bertujuan untuk mengetahui pengalaman subjektiftransenden yang luar biasa dari potensi spritual tersebut. ${ }^{26}$

Di aspek lain, embrio lahirnya Psikologi Islam sebenarnya telah dimulai di beberapa negara Islam. Perkembangan kajian di bidang psikologi sendiri juga tidak dapat dilepaskan dari pergulatan antara warisan (turâts) dan modernitas (hadâtsah). Dalam wacana publik internasional, bidang kajian ini mulai bergaung sejak tahun 1978 Pada tahun tersebut di Universitas Riyad Arab Saudi telah berlangsungInternational Symposium on Psychology and Islam. Gerakan ini berlanjut ketika Malik B. Badri, seorang psikolog Afrika, menerbitkan buku The Dilemma of Muslim Psychologistspada tahun 1979.

$\overline{25}$ Fuad Nashori, Psikologi Islami Agenda Menuju Aksi, Cet.I, (Yogyakarta: Pustaka Pelajar, 1997), hlm. 9.

26 Jalaluddin Rakhmat,Psikologi Agama: Sebuah Pengantar,Cet.I, (Bandung: Mizan, 2002), hlm. 114125. 
Buku yang mengkritik tajam Psikologi Barat ini telah mendapat sambutan yang luar biasa dan menjadi peluang bagi bangkitnya disiplin Psikologi Islam. Di Indonesia, kajian psikologi bernuansa Islam sudah dimulai oleh Zakiah Daradjat sejak tahun 60-an. ${ }^{27}$

Keinginan para intelektual muslim kontemporer untuk memberikan tawaran baru dalam bidang psikologi tidak dapat dilepaskan dari adanya keprihatian terhadap paradigma Barat yang menjadi pandangan dunia (worldview) dalam kajian psikologi modern yang bertentangan dengan pandangan dunia Islam (Islamic worldview). Beberapa karakteristik dasar yang umumnya dikembangkan dalam psikologi Barat antara lainpertama, menafikkan dimensi Tuhan dalam kajian psikologi; kedua,epistemologi yang digunakan terfokus pada empiris positivistik dan empirisisme humanistik; ketiga, tidak mengungkap ruh sebagai struktur utama kepribadian manusia; keempat,berpusat pada anthropo-sentris. Beberapa tawaran sebagai solusi atas psikologi Barat antara lain:pertama, theisme atau desekularisasi; Kedua, anthroporeligius; ketiga, dimensi ruh sebagai struktur psikis (kepribadian) utama manusia. ${ }^{28}$

Padapraktiknya, para intelektual Muslim yang terlibat dalam pengembangan kajian psikologi di dunia Muslim memang tidak satu warna. Setidaknya ada dua pola umum yang dikembangkan dalam kajian psikologi Islam, yang ternyata relevan dengan perdebatan turâts dan hadâtsah dalam diskursus muslim kontemporer, yakni yang berpijak pada turâts di satu sisi,dan yang mendasarkan pada hadâtsah di sisi lain.

\section{E. Simpulan}

Agama Islam merupakan agama wahyu yang diturunkan Allah Swt. kepada manusia guna membantu memberikan arah dan tujuan hidup mencapai derajat insan kamil, yaitu penghambaan semata-mata kepada Allah Swt. untuk memperoleh ridlo-Nya. Islam dengan nilai-nilai khas dan universalnya, memiliki daya konstruktif, regulatif dan formatif yang kuat, sehingga berpengaruh terhadap sistem kehidupan, baik secara individual

27 Ibid., hlm. 11.

28 Baharuddin, Aktualisasi...,hlm. 6. 
maupun komunal, dan yang perwujudan puncaknya pernah ditampakkan oleh eksistensi kejayaan peradaban Islam pada Abad Pertengahan.

Pendekatan psikologi dalam studi islam adalah suatu sudut atau cara pandang terhadap objek studi (Islam), yaitu dengan mempelajari aspekaspek kejiwaan yang mempengaruhi cara berpikir, bersikap, dan berperilaku individu dan atau komunitas muslim dalam konteks keberagamaannya. Kematangan jiwa individu dan umat Islam dalam rangka merealisasi dan memproses pencapaian tujuan dan keseimbangan hidup, dipengaruhi oleh variabel pemahaman (kognitif), penghayatan (afektif) dan pengamalan (psiko motorik/perilaku) terhadap nilai-nilai keislaman dalam kehidupan seharihari. Pendekatan psikologi dalam studi Islam berfungsi untuk membantu pemahaman, pengendalian dan peramalan terhadap perilaku keberagamaan individu dan atau komunitas Muslim.

\section{Daftar Pustaka}

Ayoub,MahmoudM, 2004. Islam: Antara Keyakinan \& Praktik Ritual, Refleksi Cendikiawan Muslim Untuk Kesadaran dan Kesatuan Umat.Terj. Nur Hidayat, Yogyakarta: AK. Group.

Baharuddin. 2005.Aktualisasi Psikologi Islam, Cet.I.Yogyakarta: Pustaka Pelajar,

Bloom,Paul. 2012. Religin Morality,Evolution. Yale University, Sterling Chemistry Library.

Baharudiin. 2004.Paradigma Psikologi Islam.Yogyakarta: Pustaka Pelajar.

Bakran, Hamdani. 2008. Konseling dan Psikoterapi Islam.Yogyakarta: Al Manar.

Daradjat,Zakiah. 1987.Ilmu Jiwa Agama.Jakarta: Bulan Bintang.

Ghazali,Adeg Muchtar. 2000. Ilmu Perbandingan Agama.Bandung: CV Pustaka Setia.

Joshi,Shobina, Shilpa Kumari \& Madhu Jain."Religious Belief and Its Relation to Psychological Well-being." Dalam Journal of the Indian Academy of Applied Psychology, Vol. 34, No.2. 2008 
Khasanah,Nur,"Kombinasi Pendekatan Studi Islam: Ikhtiar Menjawab Tantangan Studi Islam Ke Depan.” Dalam RELIGIA Vol. 15 No. 1, (April 2012).

Langgulung,Hasan. 2003. Asas-Asas Pendidikan Islam.Jakarta: Pustaka AlHusna Baru.

.1992. Teori-Teori Kesehatan Mental, Cet. II. Jakarta:

Pustaka al-Husna.

McCullough,Michael E. and Brian L. B. Willoughby. "Religion, SelfRegulation, and Self-Control: Associations, Explanations, and Implications." DalamPsychological Bulletin, Vol. 135, No. 1.2009.

Nashori,Fuad.1997. Psikologi Islami Agenda Menuju Aksi, Cet.I.Yogyakarta: Pustaka Pelajar.

Raharjo. 2012.Pengantar Ilmu Jiwa Agama.Semarang: Pustaka Rizki Putra.

Rahayu,Iin Tri.2009. Psikoterapi Prespektif Islam dan Psikologi Kontemporer. Yogyakarta: Sukses Offset.

Rakhmat,Jalaluddin.2002. Psikologi Agama: Sebuah Pengantar,Cet.I., Bandung: Mizan.

Sundari,Siti. 2005. Kesehatan Mental dalam Kehidupan.Jakarta: PT Rineka Cipta.

Van der Merwe, K.,"A Psychological Perspective on The Source and Function of Religion”, HTS Teologiese Studies/Theological Studies 66(1), Art. \#331, 8 pages. DOI: 10.4102/hts.v66i1.33,2010. 